\section{Mirjana Knežević ${ }^{1}$}

Zlata Đurić ${ }^{2}$

University of Kragujevac

Faculty of Economics
ORIGINAL SCIENTIFIC ARTICLE doi:10.5937/ekonomika1902039K

Received: March 13, 2019

Accepted: May, 08, 2019

\title{
SOME ASPECTS OF INSURANCE DEVELOPMENT IN SERBIA ${ }^{3}$
}

\begin{abstract}
The main purpose of incorporating insurance into the law and economy of a country is to ensure that adverse circumstances should not affect the quality of functioning. Consequently, the question is: Why is this concept not attractive for people living in underdeveloped and developing countries, where any financial compensation for the loss is almost necessary? We looked for the answer by means of two questionnaires: one examining satisfaction of voluntary insurance policy holders, and the other using respondents who have never used any form of voluntary insurance. The insights allowed us to make recommendations pertaining to what insurance companies should do to strengthen and improve their position.
\end{abstract}

Key words: insurance companies, questionnaire, insurance market

JEL Classification: K20, C1

\section{НЕКИ АСПЕКТИ РАЗВОЈА ОСИГУРАҢА У СРБИЈИ}

\section{Апстракт}

Основна сврха конституисања осигурања у правно-економски амбијент неке земље јесте пружағе сигурности да реализација неких неповољних околности неће нарушити квалитет функиионисана. Самим тим, неизбежно се намеће питане: Зашто овај кониепт није довољно примамљив становништву, посебно у неразвијеним и земљама у развоју, где је свака монетарна компензаиија губитака скоро неопхода? Одговор на ово питање потражен је кроз две анкете: једна анкета испитује задовољство корисника добровољних видова осигурања док је другом анкетом обухваћена популаџија која није користила ни један облик добровољног осигурања. На основу стечених перичепщија дате су препоруке о неопходни акцијама осигуравајућих друштава у ияиљу њиховог јачег и доминантнијег позициионирања.

Кључне речи: осигуравајућа друштва, анкета, тржиште осигурања

\footnotetext{
${ }^{1}$ mknezevic@kg.ac.rs

${ }^{2}$ zdjuric@kg.ac.rs

${ }^{3}$ The paper is part of the Project No. 47023 funded by Ministry of Education, Science, and Tehnological Development of the Republic of Serbia
} 


\section{Introduction}

Insurance market in underdeveloped and developing countries has significant potential for those insurers who realize that the vision of insurance is returning to its roots. As the number of risks is on the rise, as well as that of the poor, the question is: Why is this concept not more attractive, especially in underdeveloped and developing countries, where any financial compensation for the loss is almost necessary for the population? Are the insurers responsible for the current gap between them and the users? Is the problem on the side of the supply or that of the demand?

To increase their profit, the insurers have developed and directed their products to financially strong clients, whose insurance coverage can bring large income. However, as the competition in this field has become very strong, the insurers are now turning to the huge segment of world population struggling with existential problems. The insurers' efforts to create a global offer obviously lack success. All they can do to reach the beneficiaries is to stop focusing on profit and start focusing on the needs of the target market.

To detect the problems pertaining to the development of the insurance market in the Republic of Serbia, this paper is divided into four parts. The first part analyzes the effects of insurance on economic development. To identify the reason for decelerated interaction between insurers and beneficiaries, we asked holders of voluntary insurance policy for opinion on insurers' services. The results of the survey are presented in the second part of the paper. In the third part, we conducted a survey among the respondents of different age and education, who have not used voluntary insurance, to determine whether the problem lies on the side of the supply or that of the demand. The fourth part of the paper contains a comparative analysis of the answers obtained in these surveys with those obtained in the developed and underdeveloped EU countries. In the conclusion, we present suggestions for the insurers based on global and local perceptions of their policy holders.

\section{Economic importance of insurance}

The importance of the insurance sector for economic development was recognized at the founding session of the United Nations Conference on Trade and Development in 1964 (UNCTAD, 1964), where Annex A.IV.23 emphasizes that 'a sound national insurance and reinsurance market is an essential characteristic of economic growth', which is why developed countries should give their full co-operation to the developing countries to strengthen their insurance and reinsurance markets. (UNCTAD, 1964, p. 55).

François Outreville gives an overview of 85 empirical studies (Outreville, 2013), examining the influence of economic development on the demand for insurance products, as well as the impact of insurance sector development rate on the growth of national economy.

Contrary to the influence of the activities of banking and stock exchange market, specificities of insurance play a key role for economic growth as they: stimulate financial stability of companies, promote entrepreneurship, encourage investment and innovation, mobilize domestic savings and accumulation of new capital and encourage production 
and consumption потрошње (Chen, 2012; Ghosh, 2013; Garcia, 2012; Chang, 2014; Pradhan, 2017). This makes the growth of insurance in developing countries all the more important, especially as these countries comprise more than $80 \%$ of world population (Outreville, 2013) while their share in global economy steadily increases.

The European Insurance and Reinsurance Federation (CEA) points out that in the world characterized by social and economic changes, insurance provides efficient help to the state through non-mandatory pension programs, as well as health and social security programs. In the guidelines, the Federation claims that the insurance sector guarantees stable income level, limits the influence of demographic changes on the state budget, while compensations and rehabilitations of workers from other countries contribute to high quality social protection. (CEA, 2006)

\section{The analysis of satisfaction of voluntary insurance policy holders}

Historically speaking, the development of insurance, together with economic and technological growth has lead to social protection of the population capable of work. Various forms of security for the workers and their family members in the case of illness or reduced productivity due to injuries have reduced the need to buy additional insurance coverages. Insurance companies turned to commercial clients and offered their services to corporations facing numerous risks (Miladinović, 2017). As the competition in this field grew more intense, many insurers now turn to uninsured population to make room for further growth and increase their profit (Počuča \& Krstinić, 2013).

The insurers' most powerful ally to achieve this goal is an offer that suits the needs of potential policy holders. To detect the drawbacks and identify the room for market position improvement, it is necessary to analyze the existing offers of insurance companies. Recognizing how important insurance development is for the economic stability of the Republic of Serbia during EU integrations, the answer to these questions was firstly elicited from the holders of some form of voluntary insurance policy.

The questionnaire was distributed to residents of several central Serbia towns in 2017. The questions focused on various interaction factors, pertaining to the respondents' awareness of offers, availability of necessary information, satisfaction level, willingness to renew the contract or recommend their choice to friends and colleagues. We also looked for reasons for dissatisfaction in terms of services that, according to beneficiaries' needs and experiences, need improvement.

The responses were analyzed according to respondents' age, gender, education, employment status, as well as according to whether they bought the insurance policy from a domestic or a predominantly foreign insurer. Out of 1615 respondents, $56.97 \%$ were male, $43.03 \%$ were female, and they were divided into three age groups: under $30(24.46 \%)$, between 30 and $50(46.13 \%)$ and above $50(29.14 \%)$. When it comes to employment status, $30.03 \%$ were unemployed. Among the employed, $27.24 \%$ work for state-owned companies, $32.51 \%$ work for privately-owned companies, while $10.22 \%$ work in their own companies. The majority of respondents had secondary education $(53.87 \%), 26.32 \%$ had high education, while the smallest portion had higher education (19.81\%). Although domestic market is dominated by foreigh insurance companies, the number of policy holders who bought their insurance from a national insurer $(40.25 \%)$ 
was almost equal to that of beneficiaries who acquired their policy from a foreign-owned insurance company $(50.46 \%)$.

On the whole, the policy holders are satisfied with the products they bought. The money they put towards security matches their expectations, so that $34.67 \%$ consider it useful, $32.82 \%$ consider it reliable, while very few respondents think that the coverage of loss was of low quality (3\%).

They show their satisfaction by staying loyal to the chosen insurer, since more than a third of the respondents (36.84\%) have remained with the same insurer for more than three years. Speaking of insurance density level in our country, it is encouraging that for $18 \%$ of the respondents this was the first voluntary insurance coverage. The policy holders will share their positive experience with their colleagues and friends very likely (52.94\%), or certainly $(32.20 \%)$, so that $75.23 \%$ are willing to renew the contract with the same insurer.

Encouraging results were also obtained when satisfaction of new policy holders - the first-time users of voluntary insurance - was examined. The purchased product is considered to be extremely useful and reliable by $68.96 \%$ respondents, so that $64.7 \%$ of them would renew the contract on voluntary insurance with the same insurance company, while $62 \%$ would probably recommend their insurer to their friends.

According to the Statistic Calendar of the Statistical Office of the Republic of Serbia (SORS), only $16.24 \%$ of the population has higher or high education. (Statistical Office of the Republic of Serbia, 2018).

For this reason, it is interesting to examine the perception of obtained service of those with lower education, as they are the largest target group for the insurers. Our survey included $53.87 \%$ respondents with secondary education. $40.80 \%$ of them have remained with the same insurance company, while a small percentage, around $9 \%$, consider their insurance to be overpriced and poor quality. Majority of these respondents will maintain the cooperation with the chosen insurer $(67.82 \%)$, while $77.85 \%$ will recommend the services to their colleagues and friends.

When it comes to buying power, or employment status, the respondents were categorized as: unemployed, employed at the state-owned company, employed at the privately-owned company and employed in their own company. Although users of voluntary insurance are undoubtedly well aware of the importance of and the need for insurance protection, this awareness is most prominent in subjects employed in their own company. $48.48 \%$ of the respondents in this group consider the purchased product useful, $24.24 \%$ consider it reliable, while $63.64 \%$ will remain loyal to the chosen insurance company.

The study has also shown that low standard of living is not the main reason for the weak position of the insurers. Quite contrary, as much as $30.03 \%$ of the unemployed respondents have been clients of the same insurer for years, while $69.07 \%$ will very probably renew their contract with the chosen insurer.

Domestic insurance companies inspire trust and loyalty in their clients, as $81.25 \%$ of their clients intend to maintain the cooperation with them, in comparison to $69.33 \%$ respondents who claim they will remain with foreign insurers. Domestic insurance companies also lead when it comes to customer satisfaction, as $69.38 \%$ of the policy holders consider the purchased insurance reliable and useful, in comparison to $65.6 \%$ of foreign insurers' policy holders.

Agents and staff of insurance companies are the main source of information about the characteristics of the insurance protection for $52.10 \%$ of the respondents, and only $19.20 \%$ of our subjects get their information from the insurers' web page. 
The choice of the insurance company (the offered answers were: randomly, on a friend's recommendation, because of the best terms, because of the best price, and because of the advertisement) is predominantly based on a recommendation of a friend $(40.43 \%)$. Almost half of these respondents $(50.38 \%)$ have secondary education, $46.56 \%$ of them are between 30 and 50, and they mostly work in privately-owned companies.

Awareness that some form of voluntary insurance coverage is necessary guides $26.29 \%$ of the respondents to choose the insurance with best insurance protection terms. The best price is decisive only for $8 \%$ of the respondents, majority of which are unemployed, predominantly male $(50.57 \%)$ with secondary education. The smallest number of respondents relies on insurers' advertisements (4.64\%), and they are predominantly employed in state-owned companies, aged between 30 and 50 and they purchase their insurance coverage from a domestic insurer.

Policy holders mostly purchase different forms of voluntary insurance from the same insurer, because they find it much easier and faster (43.03\%). Only 22\% of the respondents claimed that high satisfaction with the chosen insurer motivated them to extend and renew their insurance coverage. $57.75 \%$ of domestic insurers' clients are satisfied. In terms of education, the percentage of satisfied policy holders with secondary education is similar, more than half of which are male $(50.7 \%)$.

Despite these findings, the survey has also detected the reasons for dissatisfaction, or the segments that insurers should improve (Figure 1). To strengthen the cooperation with their clients, the insurers should make their offer more transparent $(18.89 \%)$. Transparency of price is important for $17.03 \%$ of the respondents. $15.48 \%$ of the policy holders feel that damage compensation program should be improved, while a large number of them expect loyalty rewards $(39.63 \%)$. The clients of domestic insurance companies feel that their insurers lack loyalty program, transparency of offer, a better damage compensation program, price transparency and easy access. The order of aspects that foreign insurers should polish is slightly different. Their clients feel that there is most room for improvement when it comes to loyalty program, followed by price transparency, better damage compensation program, transparency of offer, and finally ease of access.

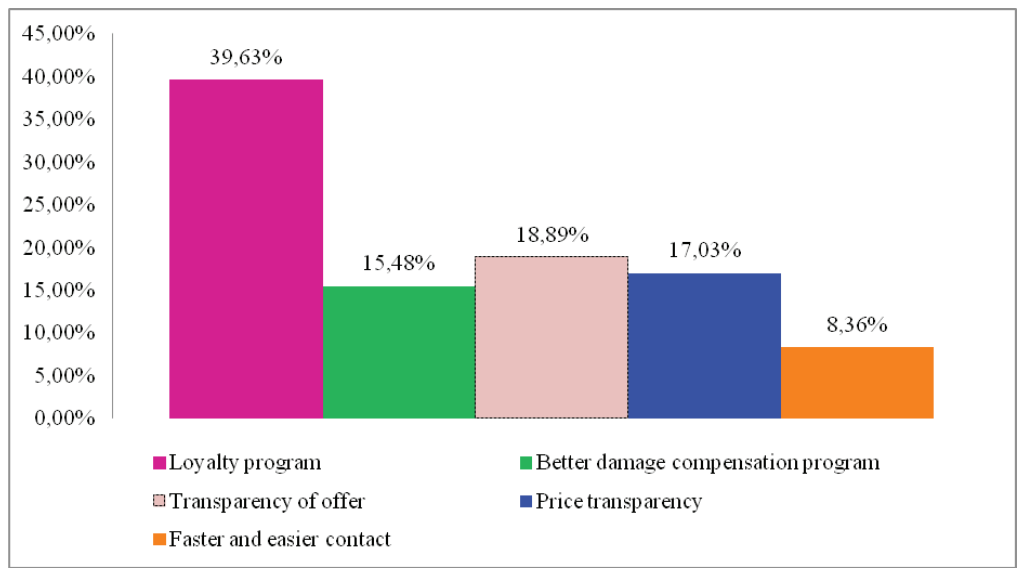

Figure 1: Which aspects should your insurer improve? Source: Authors' research, 2018. 
Criticism leveled at loyalty program was predominantly made by male beneficiaries $(57.03 \%)$ aged between 30 and $50(46.09 \%)$ with secondary education $(52.34 \%)$, more than a third of whom works for private companies (34.38\%).

The primary motive, especially in underdeveloped countries, for purchasing some form of voluntary insurance coverage is to obtain financial compensation for a suffered loss. Consequently, the quality of damage compensation program is the aspect that beneficiaries are most interested in. This is what $15.48 \%$ of the respondents identified as the aspect which insurers should improve. Most of these respondents were male (76\%), aged between 30 and 50. Damage compensation is, understandably, most important for the unemployed (38\%). In terms of education, $52 \%$ of the respondents had secondary education. When it comes to the choice of the insurer, most of them where insured at foreign-owned insurance companies (54\%).

Insurers should also correct their customer retention policy. The respondents claim that insurers mostly offer extended coverage (44.89\%), but as many as $29.41 \%$ of the respondents informed us that the insurer showed no initiative to maintain the cooperation with them (Figure 2). Foreign-owned insurers showed more motivation to keep the existing policy holders.

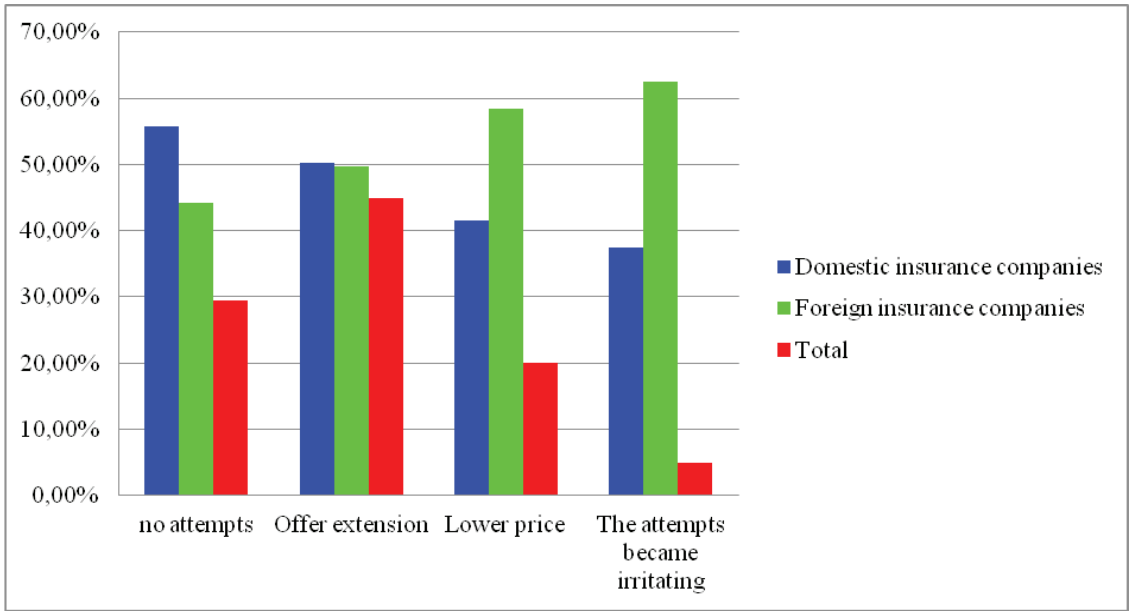

Figure 2: In which way and how hard did the insurer try to convince you to remain their client?

Source: Authors' research, 2018.

People employed in their own companies, who are more motivated to get insurance than those working for state-owned or private companies, claim that domestic insurers frequently ignore them as clients which should be retained. First-time users of voluntary insurance also claim that foreign insurers were more interested in keeping them as clients (by extending the offer or lowering the price). This piece of information is certainly important for domestic insurance companies, as most policy holders base the choice of the insurer on the recommendation of their friends and colleagues. 
The reasons why insurance is not more popular in the Republic of Serbia can also be identified on the side of the demand for some form of voluntary insurance coverage. When asked if they would like an extension of their insurance protection, through packages comprising several kinds of insurance, $48.30 \%$ policy holders replied that they did not need more protection. Large number of policy holders (32.82) lacks information regarding possible extensions, while $18.89 \%$ find that the packages on offer do not suit their needs. This certainly gives insurers a chance to enhance their offer to fit the clients' needs.

Low awareness of advantages of insurance protection can be observed at all education levels since all the categories (secondary, higher and high education) predominantly feel they do not need higher protection against risks.

\section{Development perspectives and future policy holders}

Economic uncertainty, together with intense competition and market risks, drives insurers to a constant, frequently unfair fight for new clients. The same economic uncertainty makes it difficult for the people facing existential problems to see the need for and advantages of insurance protection. Insurers' perceptions of clients' behavior should be reexamined, since only those who understand the attitudes and dilemmas of potential clients can manage to gain their trust.

The questionnaire pertaining to attitudes and inhibitions regarding voluntary insurance was distributed in several towns. The authors obtained responses from 990 subjects, who were as follows: $37.69 \%$ male, $62.31 \%$ female; $49.24 \%$ under $30,35.56 \%$ between 30 and 50, 15.20\% above 50. According to employment status, most of them were unemployed $(53.80 \%)$, out of which $58.19 \%$ have secondary education, $11.86 \%$ have higher and $29.94 \%$ have high education.

The majority of unemployed respondents is under $30(68.35 \%)$, and $15.82 \%$ of them have higher education, while $16.38 \%$ of them have high education.

The structure of the working respondents is as follows: $28.21 \%$ work for private companies, $14.89 \%$ work in state institutions, while $2.74 \%$ work in their own companies. When it comes to private companies, $61.29 \%$ of the respondents have secondary education, while $19.35 \%$ have higher or high education. $33.33 \%$ of the respondents are under $30,54.84 \%$ are between 30 and 50 , while $11.83 \%$ are over 50 . Out of those working for state institutions, $38.78 \%$ have secondary education, $65 \%$ have higher, while $28.57 \%$ have high education. In terms of age, $63.26 \%$ of the respondents were between 30 and 50 , while $18.38 \%$ of them have secondary or high education.

The responses to the question whether they plan to purchase some form of voluntary insurance are presented in Figure 3. The smallest portion of the respondents $(13.37 \%)$ thinks that they do not need such coverage against unwanted risks. Low awareness of insurance advantages prevails among women (52.27\%), people under $30(45.45 \%)$, the unemployed (53.33\%) with secondary education $(71.64 \%)$. 


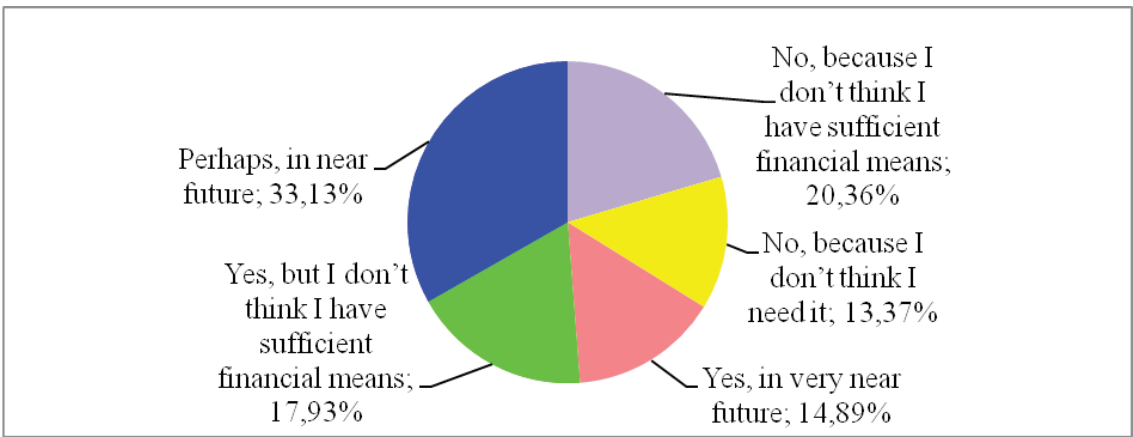

Figure 3: Do you plan to purchase some form of voluntary insurance?.

Source: Authors' research, 2018.

When asked about purchasing insurance, the respondents replied that they: a) would make the purchase if somebody informed them about the offers and prices $42.68 \%$; b) would make the purchase in case of adverse incident $-40.73 \%$; c) would purchase voluntary insurance together with mandatory $-16.59 \%$.

When it comes to insurance offers and conditions, $24.32 \%$ of the respondents have no, while $70.52 \%$ have little information about it. $5.17 \%$ of the respondents claim to be fully informed: $17.68 \%$ of them obtained all the information on the Internet, $58.82 \%$ obtained it from an agent, while $23.53 \%$ got it from a friend. Potential policy holders most frequently obtain information about insurance coverage from a friend $(33.13 \%)$, while the smallest segment of them (only 19.45\%) gets it from insurance agents.

The respondents tend to purchase their insurance at the insurance company's office $(64.44 \%)$, or from an insurance agent $(32.52 \%)$. They mistrust online purchase, and only $3.04 \%$ would buy insurance coverage over the Internet. In addition, personal contact plays an important part in this, primarily because they need additional information (52.89\%), expert advice when making financial decisions $(30.40 \%)$, while $15.81 \%$ have problems with the paperwork.

The uninsured population mostly feels the need for life insurance (47.42\%), followed by voluntary health insurance $(21.28 \%$ ), while $29.18 \%$ would purchase some form of property insurance. When purchasing insurance, they feel that quality $(67.17 \%)$ is more important than the price $(31.91 \%)$.

These results suggest that people are aware of the importance of insurance coverage, but their low living standard prevents them from purchasing some form of voluntary insurance. Beyond doubt, many respondents would realize that they are financially capable of paying insurance coverage if insurers took some effort to inform them about it.

\section{Comparative analysis of satisfaction of domestic and $\mathrm{EU}$ beneficiaries}

Insurance industry is going through revolutionary changes in terms of regulations, through implementation of stronger and more cautious solvency supervision by 
implementing Directive Solvency 2 (Tošić, 2017). The regulators focus the supervision on insurer's ability to meet numerous business risks. As interaction with beneficiaries is most important for insurance companies, this segment should be permanently analyzed and corrected. Listening to purchasers' opinions and dilemmas provides valuable information and becomes integral part of competitive strategy. The insurance sector has numerous specificities. Therefore, deeper understanding of consumers' basic motives, where awareness of insurance protection advantages is low, will help managers design a more attractive offer and increase their market share.

Ernst \& Young company conducted in 2011 a global research on insurance purchasers, starting from the fact that 'previous assumptions and received wisdom about customers may no longer be reliable, and those insurers who are able to respond best to what customers want now are most likely to succeed' (Ernst \& Young, 2012). Their survey covered 23 countries in seven world regions, encompassing 8532 policy holders in eight European countries: France, Germany, Italy, Holland, Poland, Spain, Turkey and Great Britain. Although the selected countries vary in terms of economic and demographic characteristics, it detected high consistency of purchasers' motives and preferences (Ernst \& Young, 2012). The findings of this survey were compared with the opinions of Serbian policy holders in order to analyze the present state and future perspectives of insurance companies doing business in the market of the Republic of Serbia.

The European respondents show high satisfaction with insurers' service (from $66 \%$ to $70 \%$ ), yet it is lower than the satisfaction of domestic policy holders, out of which only $5.57 \%$ claimed that the purchased product was overpriced and of poor quality (Herman, 2012).

Although our insurance market is underdeveloped and our sample smaller (1615 in comparison to 8532 in Europe), the criticism is very similar. Both domestic and international insurance policy holders complain about the lack of loyalty programs, ask for better availability, more transparent offer and easier access to the Internet information. While $5.17 \%$ of domestic respondents claim to be fully informed about the insurance offers, $27 \%$ of European policy holders obtain detailed information before the purchase. When purchasing life insurance, they obtain their information from family and friends, Internet sources and compare offers from insurers' web pages. Holders of other insurance policies rely much more on the information from the Internet, although they make the online purchase far less frequently. Personal contact is most important for approximately $50 \%$ of the EU respondents, as they need additional information and expert advice when making important financial decisions. However, life insurance policy buyers do not want to purchase several products from the same insurer. What motivates them to remain with the same insurer is the price reduction (20\%), while $16 \%$ want insurance coverage extension at the same price.

The opinions of non-life insurance policy holders diverge from these findings, as they feel that, apart from the price (which plays the key role when purchasing) the brand is also important, so that $31 \%$ of them would pay a higher price for a financially stable brand. Almost half of these respondents (49\%) want to purchase several products from the same insurer, for reasons of simplicity and trust. However, a high percentage of buyers $(82 \%)$ have changed the insurance company because the agents took no trouble to retain them as customers. 
The foregoing indicates that, regardless of the sample size, findings pertaining to customer satisfaction and insurers' performance are almost identical in the domestic and EU market. The differences pertain to less intense Internet activity of the Serbian people, since only $19.20 \%$ of domestic respondents obtain information about insurance offer online, as opposed to $35 \%$ EU insurance policy holders. (Njegomir, Tepavac \& Počuča, 2013).

In addition, many foreign respondents made the choice of the type of insurance and the insurance company after comparing information from web pages, contrary to domestic insurance policy holders.

\section{Conclusion}

Customer satisfaction of domestic and EU insurance policy holders is extremely high, which speaks well of the insurers, at the same time indicating directions for business policy corrections. Underdevelopment of the insurance market in the Republic of Serbia suggest that insurance companies must make revolutionary changes, including technological modernization, creation of products attractive to the growing middle class and development of new sales channels and methods. They should also make use of simplified marketing activities to demystify their products in terms of price, importance and content of insurance coverage.

The results of the survey suggest that more efficient sales channels should be found to persuade the people that their ability to purchase protection against numerous risks is high, especially when compared to the potential damage. Since we have detected the customers' habit to base their choice of the insurer on opinions of friends and relatives, insurers should continuously monitor and improve satisfaction of current and future insurance policy holders, primarily by loyalty programs, which are plenty in other market segments.

Insurance companies' management must stimulate agents to turn more attention to the huge number of uninsured people, because if they find the right way to gain their trust and make them aware of the quality of insurance product, financial compensation may be even larger than that from commercial insurance policy holders.

This multidirectional activity must be supported by regulations, based on customer protection and education, accompanied by popularization of some basic voluntary pension, health and life insurance. The state should also intervene to create conditions for the development of potent insurance industry by investing in modernized systems for data collection and processing, needed for the expertise and identification of most profitable development and investment activities. To implement this, it is necessary to improve the system of education which can provide better quality information about this market and educate the needed staff.

High sales potential is an adequate encouragement for the insurers to set off on this long and hard journey, which will, accompanied by state intervention, bring benefit for all stakeholders, especially general population. 


\section{References}

CEA. (2006). Insurers of Europe, The Contribution of the Insurance Sector to Economic Growth and Employment in the EU, Brussels.

Chen, P.F., C.C. Lee, \&C.F. Lee. (2012). How does the development of the life insurance market affect economic growth? Some international evidence. Journal of International Development 24(7): 865-93.

Ernst \& Young (2012). Voice of the Customer: Time for Insurers to Rethink Their Relationships - Global Consumer Insurance Survey 2012. Technical Report, Ernst \& Young Global Limited, London.

Garcia, M. T. M. (2012). Determinants of the property-liability insurance market: evidence from Portugal. Journal of Economic Studies, 39: 440-450.

Ghosh, A. (2013). Does life insurance activity promote economic development in India: An empirical analysis. Journal of Asia Business Studies, 7: 31-43

Hassan, M. Kabir, Sanchez, Benito, \& Yu, Jung-Suk (2011). Financial development and economic growth: New evidence from panel data. The Quarterly Review of Economics and Finance 51: 88- 104.

Herman, V. (2012). The relation between the right to pension insurance and marital property rights in comparative European systems. Pravo - teorija i praksa, 29(1-3): 60-73.

Miladinović, A. (2017). Saosiguranje u Republici Srbiji. Pravo i privreda, 55(7-9): 482-495

Njegomir, V., Tepavac, R., \& Počuča, M. (2013). Kapacitet međunarodnog sektora osiguranja i reosiguranja - implikacije katastrofalnih šteta. Međunarodna politika, 64(1149): 137-156.

Outreville, F.J. (2013).The relationship between insurance and economic development: 85 empirical papers for a review of the literature. Risk Manag Insurers Review, 16(1):71-122

Outreville, J. F. (1990). The economic significance of insurance markets in developing countries. The Journal of Risk and Insurance, 57( 3): 487-498

Počuča, S., \& Krstinić, D. (2013). Istorijski razvoj životnog osiguranja. Pravo - teorija i praksa, 30(4-6): 25-34.

Pradhan, Rudra P.; Dash, Saurav; Maradana, Rana Pratap; Jayakumar, \& Manju; Gaurav, Kunal. (2017). Insurance market density and economic growth in Eurozone countries: the granger causality approach. Financial Innovation 3(17): 1-24

Republički zavod za statistiku (2018). Statistički kalendar Republike Srbije. Beograd, 2018

Sami Ben Naceur, Robert Blotevogel, Mark Fischer, \& Haiyan Shi. (2017). Financial Development and Source of Growth: New Evidence. IMF Working Paper $\mathrm{WP} / 17 / 143$

Tošić, I. (2017). Izazovi u imlementaciji Direktive Solventnost II u Srbiji, Pravo $i$ privreda, 55(7-9): 526-541

UNCTAD (1964). Proceedings of the United Nations Conference on Trade and Development, Vol. I, Final Act and Report, p. 55, annex A.IV.23. 